\title{
PENINGKATAN PERKEMBANGAN KOGNITIF DALAM MENGENAL ANGKA MELALUI MEDIA PUZZLE DI TAMAN KANAK-KANAK
}

\author{
Dwi Angraeni ${ }^{1}$ \& Bonita Mahmud ${ }^{2}$ \\ ${ }^{1}$ Pendidikan Guru Pendidikan Anak Usia Dini, Universitas Negeri Makassar \\ ${ }^{2}$ Pendidikan Guru Pendidikan Anak Usia Dini, IAIN Bone
}

\begin{abstract}
:
The problem in this research is that children cannot recognize numbers in group B PAUD Terpadu Teratai UNM Makassar City which can be solved in standard with puzzle games. The purpose of this study was to describe the cognitive development in recognizing numbers through the media puzzle in group B PAUD Terpadu Teratai UNM Makassar City. The focus of this research is how to increase cognitive development in recognizing numbers through puzzle media. The subjects of this study were teachers and children in group B. The results showed that the activities of the teacher at the second meeting of the first cycle only reached $40 \%$, so it was still in the poor category, the second meeting of the second cycle reached $80 \%$, then it increased to be a good category. Likewise, the learning activities of students at the second meeting of the first cycle only reached $38 \%$, so it was still in the sufficient category, the second meeting of the second cycle had reached $84 \%$, so it increased to be a good category. Based on the results of the research, the ability to recognize numbers through the media of puzzles in the Integrated PAUD Teratai UNM Makassar City has increased.
\end{abstract}

Keywords: Cognitive development, puzzle media, recognizing numbers.

\begin{abstract}
Abstrak:
Masalah dalam penelitian ini yaitu anak belum dapat mengenal angka pada anak kelompok B PAUD Terpadu Teratai UNM Kota Makassar yang dapat diatasi pada standar dengan permainan puzzle. Tujuan penelitian ini adalah untuk mendeskripsikan perkembangan kognitif dalam mengenal angka melalui media puzzle pada anak kelompok B PAUD Terpadu Teratai UNM Kota Makassar. Fokus penelitian ini adalah bagaimana peningkatan perkembangan kognitif dalam mengenal angka melalui media puzzle. Subjek penelitian ini adalah guru dan anak kelompok B. Hasil penelitian menunjukkan bahwa aktifitas guru pada pertemuan II siklus I hanya mencapai $40 \%$ maka masih dalam kategori kurang, pertemuan II siklus II mencapai $80 \%$ maka meningkat menjadi kategori baik. Demikian pula aktivitas belajar anak didik pada pertemuan II siklus I hanya mencapai $38 \%$ maka masih dalam kategori cukup, pertemuan II siklus II sudah mencapai $84 \%$ maka meningkat menjadi kategori baik. Berdasarkan hasil penelitian Kemampuan mengenal angka Melalui Media Puzzle di PAUD Terpadu Teratai UNM Kota Makassar Meningkat.
\end{abstract}

Kata Kunci: Perkembangan kognitif, media puzzle, mengenal angka. creativecommons.org/licenses/by-nc/4.0/). Received: Mei 2019, Accepted: Mei 2019, Published: Juni 2019 


\section{PENDAHULUAN}

Taman kanak-kanak merupakan lembaga pendidikan yang ditujukan bagi anak-anak usia 4-6 tahun untuk melaksanakan suatu proses pembelajaran agar anak dapat mengembangkan potensi-potensinya sejak lahir sehingga anak dapat berkembang secara wajar sesuai dengan tahap usianya. Melalui pembelajaran di taman kanak-kanak diharapkan anak tidak hanya siap untuk memasuki jenjang pendidikan sekolah dasar, tetapi yang lebih utama agar anak memperoleh rangsangan-rangsangan fisik motorik, intelektual, nilai agama dan moral, sosial dan emosional sesuai dengan tingkat usianya karena dalam kegiatan belajar ada tujuan yang akan dicapai.

Tujuan program kegiatan belajar anak taman kanak-kanak adalah untuk membantu meletakkan dasar kearah perkembangan sikap, pengetahuan, keterampilan, dan daya cipta yang diperlukan oleh anak didik dalam menyesuaikan diri dengan lingkungannya dan untuk pertumbuhan dan perkembangan selanjutnya. Undang-undang nomor 20 tahun 2003 tentang sistem pendidikan nasional pasal 1 menyatakan bahwa pendidikan anak usia dini (PAUD) adalah suatu upaya pembinaan yang ditujukan pada anak sejak lahir sampai dengan usia enam tahun yang dilakukan dengan pemberian rangsangan pendidikan untuk membantu pertumbuhan dan perkembangan jasmani dan rohani agar anak memiliki kesiapan dalam memasuki pendidikan anak usia dini.

Program pendidikan anak usia dini direncanakan, dikembangkan, dikelola dan dievaluasi dengan model dan pendekatan yang sangat khusus disesuaikan dengan karakteristik subyek didiknya dalam hal ini anak. Program pendidikan anak yang dirancang secara khusus ini tentu membutuhkan pemahaman yang luas dan utuh dari para guru sehingga kesalahan-kesalahan yang sering terjadi misalnya guru menganggap bahwa program pendidikan untuk siapa saja intinya sama, tidak terjadi lagi. Melalui program pendidikan yang dirancang dengan baik, anak akan mampu mengembangkan segenap potensi yang dimilikinya, baik dari aspek fisik, sosial, moral, emosi, kepribadian kognitifnya. Salah satu bidang pengembangan yang dilakuakn di TK adalah aspek pengembangan kognitif. Depdiknas (2007: 1) Perkembangan kognitif bertujuan agar anak mampu mengelolah perolehan belajarnya, menemukan bermacam-macam alternatif pemecahan masalah, mengembangkan kemampuan logika-matematika,pengetahuan ruang dan waktu, kemampuan memilah dan mengelompokkan dan persiapan pengembangan kemampuan berfikir teliti.

Pengenalan angka sangat penting dikuasai oleh anak, sebab anak menjadi dasar bagi penguasaan konsep-konsep matematika selanjutnya di jenjang pendidikan berikutnya. Untuk menyatakan suatu bilangan dinotasikan dengan lambang bilangan yang di sebut angka (Sudaryanti, 2006). Ketika kegiatan pembelajaran mengenal lambang bilangan, guru seringkali menggunakan buku tulis maupun menuliskannya di papan tulis. Hal tersebut dapat membuat anak menganggap bilangan sebagai rangkaian kata-kata yang tidak bermakna dan pembelajaran mengenal labang bilangan merupakan hal yang membosankan, sehingga guru harus menggunakan metode serta media yang menarik dan menyenangkan dalam mengenalkan angka tersebut.

Berdasarkan hasil observasi yang telah di lakukan di Kelompok B PAUD Terpadu Teratai UNM Kota Makassar pada tanggal 2 Februari 2016 bahwa perkembangan kognitif anak dalam mengenal angka melalui media puzzle masih tergolong rendah. Hal ini di lihat 
pada saat anak menyusun puzzle yang di terapkan di dalam kelas, pembelajaran yang digunakan masih konvensional, pembelajaran masih berpusat pada guru,juga disebabkan oleh faktor guru dimana guru kurang melibatkan anak secara aktif dalam pembelajaran. diharapkan dapat memperbaiki atau meningkatkan praktek pembelajaran di kelas secara efektif dan efisien sehingga anaklebih bersemangatdalam meyusun puzzle dengan tiga tahapan yaitu (1) tahap persiapan, (2) tahap pelaksanaan, (3) tahap tindak lanjut. masih banyak anak-anak yang tidak konsentrasi dalam menyusun puzzle. Padahal dalam menyusun puzzle dapat membantu anak dalam perkembangan kognitifnya mengenal angka. Hal tersebut disebabkan kerena jarangnya anak-anak di latih dalam menyusun puzzle.sesuai dangan pendapat Susanto (2011: 47) bahwa "kognitif adalah suatu proses berpikir, yaitu kemampuan individu untuk menghubungkan, menilai, dan mempertimbangkan suatu kejadian atau peristiwa”. Sejalan dengan pendapat Pamela Minet (Sujiono, 2006) mendefinisikan perkembangan kognitif adalah perkembangan pikiran. Pikiran yang digunakan untuk mengenali, memberi alasan rasional, mengatasi dan memahami kesempatan penting. Pikiran anak mulai aktif sejak lahir, dari hari kehari sepanjang pertumbuhannya. Perkembangan pikirannya, seperti : 1) belajar tentang orang; 2) belajar tentang sesuatu; 3) belajar tentang kemampuan-kemampuan baru;4) memperoleh banyak ingatan; dan 5) menambah banyan pengalaman sepanjang perkembangannya pikiran anak, maka anak akan menjadi lebih cerdas.beberapa pendapat diatas peneliti dapat menyimpulkan bahwa perkembangan kognitif adalah proses menyatukan informasi yang didapat dari lingkungan dan kematangan anak.pengenalan angka bertujuan agar anak memiliki kemampuan untuk berpikir logis terhadap benda-benda konkrit yang melibatkan angka sehingga anak dapat bersosialisasi dan menyesuaikan diri dalam kehidupan bermasyarakat khususnya aktivitas yang berkaitan dengan angka.

Ismail (2006: 218) "puzzle merupakan permainan dengan menyusun gambar atau benda yang telah dipecah dalam beberapa bagian. Soebacham (2012) puzzle adalah permainan terdiri atas kepingan-kepingan dari satu gambar tertentu yang dapat melatih kreativitas, keteraturan, dan tingkat konsentrasi”. Bermain puzzle suatu cara dimana kegiatan yang dilakukan oleh anak-anak adalah untuk memperoleh kenangan melalui melalui permainan yang dimainkan dengan cara membongkar dan memasang kembali kepingan-kepingan gambar yang telah dipecah menjadih gambar utuh berdasarkan warna maupun bentuknya dapat melatih konsentrasi dan kreativitas anak.

\section{METODOLOGI}

Pendekatan yang digunakan dalam penelitian ini adalah pendekatan kualitatif. pendekatan kualitatif deskriptif adalah hasil penelitian beserta analisisnya diuraikan dalam suatu tulisan ilmiah yang berbentuk narasi, kemudian dari analisis yang telah dilakukan diambil suatu kesimpulan. Pendekatan penelitian ini dipilih untuk mendeskripsikan aktivitas dan kreativitas anak serta guru dalam pelaksanaan tindakan pembelajaran. Jenis penelitian yang digunakan dalam penelitian ini yaitu penelitian tindakan kelas (PTK). Menurut Arikunto (2010:3) menyatakan bahwa PTK adalah sebuah kegiatan peneliti yang dilakukan oleh guru dikelanya sendiri melalui refleksi diri dengan tujuan untuk memperbaiki kinerjanya sendiri melalui refleksi diri dengan tujuan untuk memperbaiki kinerjanya sehingga hasil belajar siswa meningkat. Di bidang pendidikan, khususnya 
kegiatan pembelajaran, PTK berkembang sebagai suatu penelitian terapan, kerena sangat bermanfaat bagi guru untukmeningkatkan mutu proses dan hasil pembelajaran di kelas.

Penelitian tindakan kelas merupakan kegiatan yang langsung berhubungan dengan tugas guru dilapangan, guru sebagai peneliti tetap melaksanakan tugas sehari-harinya, namun melakukan tindakan dalam memperbaiki pembelajaran di kelas. Esensi penelitian tindakan kelas merupakan kajian terhadap kontak situasi sosial yang dicirikan dengan adanya unsur tempat, pelaku dan kegiatan dalam waktu tertentu untuk meningkatkan kualitas tindakan. Penelitian ini dilakukan di PAUD Terpadu Teratai UNM Kota Makassar yang berjumlah 13 anak didik dan 2 orang guru, yang terdiri dari 7 anak laki-laki dan 6 anak perempuan. tindakan ini dilakukan oleh guru dan peneliti sebagai observer. Penelitian tindakan kelas ini dirancang untuk dilakukan dalam 2 (dua) siklus, yaitu setiap siklusnya diadakan 2 (dua) kali pertemuan. Serta tiap siklus mempunyai 4 tahapan, pelaksanaan, observasi, dan refleksi. Empat tahap tersebut secara berurutan dalam setiap siklus.

Teknik Analisis Data semua data yang di peroleh dari hasil observasi di analisis secara kualitatif dan kuantitatif. Dimana data kualitatif yang dimaksud adalah gambaran aktifitas mengajar guru dan belajar anak dalam pembelajaran yang menggunakan media puzzle yang dapat menigkatkan perkembangan kognitif dalam mengenal angka, dan untuk mengetahui keberhasilan pada setiap siklus. Data dari hasil analisis berdasarkan indikator pembelajaran.

\section{HASIL DAN PEMBAHASAN}

Kegiatan yang dilakukan pada tahap perencanaan ini adalah:

1. Menentukantema pembelajaran

2. Membuat rencana kegiatan mingguan dan rencana kegiatan harian.

3. Menyiapkan lagu-lagu yang dinyanyikan

4. Menyiapkan alat atau media yang akan digunakan.

5. Mengalokasikan waktu

6. Menyiapkan lembar observasi atau instrument penilaian.

Tahap pelaksanaan tindakan, tahap ini merupakan implementasi dari semua rencana yang dibuat, kegiatan yang dilakukan di kelas adalah melaksanakan tindakan yaitu mengenalkan angka dengan media puzzle. Dalam pelaksanaan penelitian ini pengamat dibantu oleh dua orang kolaborator yang bertugas untuk mengamati jalannya proses pembelajaran. Tahap observasi dilaksanakan dengan menggunakan lembar observasi yang telah dibuat, proses observasi yang dilakukan oleh observer untuk mengamati guru dalam mengajar dan mengamati anak dalam meningkatkan kemampuan mengenal angka melalui media puzzle pada anak kelompok B PAUD Terpadu Teratai UNM Kota Makassar. Tahap refleksi merupakan kegiatan menelaah hasil belajar kemampuan mengenal angka dalam menyusun puzzle pada anak kelompok B TK Teratai UNM Kota Makassar hasil observasi aktivitas mengajar guru serta aktivitas belajar anak pada siklus pertama yang dilakukan oleh guru dan observer. Tahap tersebut menganalisa keberhasilan dan kelemahan dalam pembelajaran kemampuan mengenal angka dalam menyusun puzzle pada siklus pertama dan menjadi masukan untuk dilakukan perbaikan pada siklus kedua.

Tahap tes sebagai serangkaian pertanyaan untuk mengukur pemahaman anak terhadap materi yang telah diberikan. Tes dilakukan setiap akhir siklus dengan tujuan mengukur 
penguasaan materi dalam mengenal angka melalui media puzzle untuk peningkatan perkembangan kognitif pada anak usia kelompok B PAUD Terpadu Teratai UNM Kota Makassar. Tahap Dokumentasi merupakan kegiatan atau proses pekerjaan mencatat yang dianggap penting untuk memberikan gambaran yang lebih jelas tentang proses pembelajaraan berupa arsip-arsip yang dapat memberi informasi data kemampuan mengenal angka dan dokumen berupa jumlah anak, RPPH, media puzzle angka, observasi mengajar guru dan observasi belajar anak tentang mengenal angka dan foto-foto yang menggambarkan situasi pembelajaran di PAUD Terpadu Teratai UNM Kota Makassar.

Hasil penelitian ini menunjukkan peningkatan kemampuan mengenal angka pada anak melalui media puzzle. Faktor yang dianalisis adalah keberhasilan anak dalam melaksanakan semua jenis kegiatan yang sesuai dengan indikator dari siklus I dan siklus IIdari 4 kali pertemuan adalah sebagai berikut :

1. Siklus pertama, dalam kegiatan pembelajaran yang dilaksanakan pada siklus 1 dan 2 dalam 4 kali pertemuan dengan tema yang sama terdiri dari kegiatan awal, kegiatan inti dan kegiatan penutup. Didalam siklus 1 masih banyak terdapat beberapa kekurangan dan kelemahan, sehinggga hasil yang diharapkan belum tercapai dengan baik. Hal ini dapat dilihat dari hasil observasi yang telah ada. Untuk itu peneliti perlu melanjutkan proses pengamatan pada siklus 2 .

2. Didalam siklus kedua ini, proses kegiatan pembelajaran masih sama dengan yang dilakukan pada siklus pertama. Hanya perbedaannya terdapat pada pelaksanaanya sehingga tidak mengulangi kesalahan pada siklus pertama. Peneliti memberikan penghargaan berupa pujian atau simbol bintang kepada anak yang mampu mengenal angka dan menyusun puzzle dengan baik.

Peningkatan perkembangan kognitif dalam mengenal angka pada anak PAUD Terpadu Teratai UNM Kota Makassar pada siklus I dan siklus II menunjukkan adanya peningkatan yang sangat berarti jika dibandingkan siklus I dan tahap sebelum pembelajaran. Pada siklus I rata-rata kegiatan mengajar guru kategori cukup dan kemampuan mengenal angka anak didik masih dalam kategori kurang. Maka dari itu, peneliti dan guru kelas menyimpulkan bahwa pembelajaran siklus I belum berhasil dan harus dilanjutkan ke siklus II dan hasil akhir siklus II pertemuan II menunjukkan adanya peningkatan kemampuan mengenal angka secara maksimal. Kemampuan Mengenal angka anak didik dengan menggunakan media Puzzle sangat cepat mengalami peningkatan karena stimulasi dan motivasi yang diberikan oleh guru sangat baik sehingga anak didik tertarik dengan pembelajaran yang diberikan.

\section{KESIMPULAN}

Berdasarkan rumusan masalah, hasil penelitian dan pembahasan pada bab sebelumnya, maka dapat disimpulkan bahwa penerapan bermain puzzle untuk peningkatan kemampuan kognitif dalam mengenal angka pada anak kelompok B di PAUD Terpadu Teratai UNM Kota Makassar telah mengalami peningkatan sesuai dengan target yang ingin dicapai. Hal ini ditunjukkan melalui peningkatan perkembangan kognitif dalam mengenal angka pada siklus I tergolong dalam kategori cukup, mengalami peningkatan pada siklus II dengan kategori baik. 


\section{DAFTAR PUSTAKA}

Arikunto, Suharsini, dkk. 2012. Penelitian Tindakan Kelas. Jakarta: Bumi Aksara.

Beaty, Janice J. Obervasi Perkembangan Anak Usia Dini. Jakarta: Kencana

Bungin, Burhan. (2007). Penelitian kualitatif. Jakarta: Kencana

Hamalik, oemar. 2008. Media Pendidikan. Bandung: PT Citra Aditya Bakti.

Ismail, Andang. 2006. Education Games Menjadi Cerdas Dan Ceria Dengan Permainan Edukatif. Yogyakarta : Nuansa Aksara.

Kurnia, Rita. (2010). Program Pembelajaran Pendidikan Anak Usia Dini.Pekanbaru: Cendikia Insani

Masnipal. 2013. Siap Menjadi Guru dan Pengelolah Paud Propesional. Jakarta: PT Elex Media Komputindo

Naga, Dali. S. 1990. Berhitung: sejarah dan perkembagannya. Jakarta: PT Gramedia.

Rudyanto. 2005. Pembelajaran Kooperatif Untuk meningkatkan Keterampilan Anak TK. Jakarta : Depdiknas

Soebacham, Agustina. 2012. Permainan Asyik Bikin Anak Pintar. Yogyakarta: IN Azna books.

Sriningsih, N. 2009. Pembelajaran Matematika Terpadu Untuk Anak Usia Dini. Bandung: Pustaka Sebelas.

Sudaryanti, 2006. Pengenalan Matematika Anak Usia Dini. Yogyakarta: FIP Universitas Negeri Yogyakarta

Susanto, Ahmad. 2011. Perkembangan Anak Usia Dini. Kencana:Jakarta

Sujiono, Yuliani Nurani. 2006. Metode Perkembangan Kognitif. Jakarta: Universitas Terbuka

2009. Konsep Dasar Pendidikan Anak Usia dini. Jakarta: Indeks.

Tedjasaputra, Mayke. S. 2001. Bermain, Mainan, dan Permainan Untuk pendidikan Anak Usia Dini. Jakarta: Grasindo.

Undang-Undang Republik Indonesia Nomor 20 Tahun 2013 Tentang Sistem Pendidikan Nasional Besertapenjelasannya. Jogjakarta: Buku Biru

Wahyuni dan Maureen. 2011. Manfaat Dan Tips Memilih Puzzle. www.alat-peraga. net/manfaat-dan-tips-memilih-puzzle.htm ( diakses 20 maret 2016)

Yulianti I, Rani. 2008. Permainan Yang Meningkatkan Kecerdasan Anak. Jakarta: Laskar Aksara.

Yudiasmini, Agung, Ujianti. 2014. penerapan model pembelajaran kooperatif tipe teams games tournament (tgt) berbantuan media puzzle dalam meningkatkan perkembangan kognitif, (diakses 30 februari 2016)

Yus, Anita. 2005 Penilaian Perkembangan Belajar Anak Taman Kanak-Kanak. Jakarta : Depertemen Pendidikan Nasional Direktorat Jendral Perguruan Tinggi Direktorat Pembinaan Pendidikan Tenaga Kependidikan dan Ketenagaan Perguruan Tinggi. 